\begin{tabular}{|l|l|l||}
\hline \multicolumn{2}{|c|}{ PublisherInfo } \\
\hline \hline PublisherName & $:$ & BioMed Central \\
\hline \hline PublisherLocation & $:$ & London \\
\hline \hline PublisherImprintName & $:$ & BioMed Central \\
\hline \hline
\end{tabular}

\title{
WHO says coronavirus causes SARS
}

\begin{tabular}{|l|l|l||}
\hline \multicolumn{2}{|c|}{ ArticleInfo } \\
\hline \hline ArticleID & $:$ & 4753 \\
\hline \hline ArticleDOI & $:$ & $10.1186 /$ gb-spotlight-20030417-01 \\
\hline \hline ArticleCitationID & $:$ & spotlight-20030417-01 \\
\hline \hline ArticleSequenceNumber & $:$ & 105 \\
\hline \hline ArticleCategory & $:$ & Research news \\
\hline ArticleFirstPage & $:$ & 1 \\
\hline \hline ArticleLastPage & $:$ & 4 \\
\hline \hline & & RegistrationDate : 2003-4-17 \\
\hline ArticleHistory & $:$ & OnlineDate \\
\hline \hline ArticleCopyright & $:$ & BioMed Central Ltd2003-4-17 \\
\hline \hline ArticleGrants & $:$ & \\
\hline \hline ArticleContext & $:$ & 130594411 \\
\hline \hline
\end{tabular}


The World Health Organization (WHO) today (April 16) announced that it believes the new coronavirus, dubbed "SARS virus", causes SARS (Severe Acute Respiratory Syndrome).

The organization claimed that its collaborating laboratories have concluded the coronavirus meets all four of "Koch's postulates" for a causative agent: it must be found in all cases of the disease, it must be isolated from the host and grown in pure culture, it must reproduce the original disease when introduced into a susceptible host, and it must be found in the experimental host so infected.

The key to this announcement were the last two tests, performed in monkeys by Albert Osterhaus and colleagues at the Erasmus Medical Centre in Rotterdam, one of WHO's global collaborative research network, which now consists of 13 laboratories.

Klaus Stöhr, WHO virologist and the coordinator of the network, said at a press conference today, "The people in this network have put aside profit and prestige to work together to find the cause of this new disease and to find new ways of fighting it... In this globalized world, such collaboration is the only way forward in tackling emerging diseases."

On April 12, the 29,736-nucleotide genome sequence of the virus was completed by a team at the Michael Smith Genome Sciences Centre in Vancouver, which was not a formal member of the network. The US Centers for Disease Control (CDC), part of the network, followed two days later by publishing its own sequence, slightly shorter at 29,727 nucleotides but otherwise differing by only "about ten basepairs, a trivial difference," according to Julie Gerberding, director of the CDC.

As the Canadian samples, purified at Canada's National Microbiology Laboratory in Winnipeg from SARS cases in Toronto, are so similar to the CDC's, which came directly from Asia, the likelihood is that this virus was brought from Hong Kong to Toronto by the Canadian index case. This was an elderly woman who had stayed at a Hong Kong hotel on the same floor as an infected doctor from Guandong in South China, where the disease seems to have originated.

One question still open is whether this coronavirus is truly the only virus needed to create the disease's most acute symptoms in humans. But now the virus is fully sequenced, laboratories like Frank Plummer's at the National Microbiology Laboratory which only detected minute amounts of coronavirus, in about half the cases of SARS, and some virus in people without SARS, will soon have much more effective PCR probes to search with.

Some new probes, based on small pieces of the virus discovered at the Bernard Nocht Institute in Hamburg and different from the CDC's early probes used by the WHO network, have already been created and made available commercially through the Hamburg company Artus GmbH. The Genome Institute of Singapore also promises new probes by the end of this week, and the CDC shortly after that.

According to Gerberding, apart from providing more stringent diagnostic tests for the virus, and potential long-term goals for antivirals and vaccines, the new sequence is otherwise not very helpful in determining the origins of the virus. "Unfortunately the clues from comparing it to the animal viruses have not given us any real leads... We can't say it's a mouse virus or a pig virus, or any other animal 
virus, necessarily, because it just isn't similar enough to the known species to be able to draw those conclusions," said Gerberding at a press conference.

"To understand origins, we need to go back to the very first cases of SARS that probably occurred in Guangdong Province, and do the kind of shoe-leather epidemiology that it takes to know: Who were those people? Where were they? What life were they leading? What did they come in contact with?" said Gerberding.

Gerberding did not believe the virus was mutating in Hong Kong, where some doctors claim the virus is becoming slightly more virulent, with worse cases and the first deaths of young people. Nevertheless, she added "this is a single-stranded RNA virus, and that kind of virus, as it reproduces itself, doesn't have the zipper on the other side to match up perfectly, so it makes mistakes. The HIV virus is an RNA virus that does that too. And so it is not surprising that we see new strains emerge over time. We haven't documented that yet with this virus, and I think the fact that the sequenced data from the isolate characterized in Canada and the US are so close, suggests that large mutations are not occurring. But it's biologically plausible, and we'll be keeping our eye on these strains as we go forward."

Strikingly, veterinary scientists have recently shown how easy it is to alter a coronavirus. At the Department of Infectious Diseases and Immunology of the Faculty of Veterinary Medicine, Utrecht University, Peter Rottier and colleagues manipulated the "spikes" in the outer coat of a coronavirus fatal to cats, to make a virus that infects mice instead. "These viruses recombine easily," Rottier told us. "Like other RNA viruses they have no repair mechanism, but they also have an RNA polymerase that's intrinsically suited to jumping from one template to another... because even in its normal strategy it has to jump from one part of the template to another. So if you provide a piece of foreign RNA it can easily jump onto that and integrate it into its genome."

This kind of thing could easily happen in the wild, said Rottier, for example, when two different coronaviruses infect the same cell. "If the result of a recombination was a virus which could now infect human cells, it would have a great new niche."

WHO today paid tribute to Carlo Urbani, the WHO scientist who first alerted the world to the existence of SARS in Hanoi, Vietnam, and who died from the disease in Bangkok March 29.

\section{References}

1. Michael Smith Genome Sciences Centre: SARS-associated coronavirus, [http://www.bcgsc.ca/ bioinfo/SARS/] 
2. CDC: SARS coronavirus sequencing, [http://www.cdc.gov/ncidod/sars/sequence.htm]

3. National Microbiology Laboratory, [http://www.nml.ca/]

4. Walgate R: Cause of SARS disputed. The Scientist, April 11, 2003., [http://www.the-scientist.com/ news/20030411/04]

5. Walgate R: Latest SARS evidence. The Scientist, April 4, 2003., [http://www.the-scientist.com/news/ 20030404/03/]

6. Artus GmbH, [http://www.artus-biotech2.com/en/index_flash.php]

7. Haijema BJ, Volders H, Rottier PJ: Switching species tropism: an effective way to manipulate the feline coronavirus genome. $J$ Virol 2003, 77:4528-38.

8. Dr Carlo Urbani, [http://www.timesonline.co.uk/article/0,,60-642183,00.html] 